\title{
Notes on Strobilanthes cuspidata with reinstatement of Endopogon versicolor (Acanthaceae)
}

\author{
Sinjumol Thomas ${ }^{1}$, Bince Mani $^{2}$, S John Britto ${ }^{3}$, Yunfei Deng, ${ }^{4}$ Pradeep A K ${ }^{5}$ \& E S Santhosh Kumar \\ ${ }^{1}$ Department of Botany, Carmel College, Mala, Thrissur 680 732, India \\ ${ }^{2}$ Department of Botany, St. Thomas College Palai, Kottayam 686 574, India \\ ${ }^{3}$ The Rapinat Herbarium and Centre for Molecular Systematics, St. Joseph's College Tiruchirappalli 620002 , India \\ ${ }^{4}$ Key Laboratory of Plant Resources Conservation and Sustainable Utilization, South China Botanical Garden, Chinese Academy of Science, Guangzhou \\ 510 650, P. R. China \\ ${ }^{5}$ WWI Innovative Solutions, Kottayam 686 576, Kerala, India \\ ${ }^{6}$ Jawaharlal Nehru Tropical Botanic Garden and Research Institute, Palode, Thiruvananthapuram 695 562, India
}

\section{Article history}

Received: 11 August 2019

Accepted: 05 October 2019

Published: 01 January 2020

\section{Publisher}

Horizon e-Publishing Group

\section{*Correspondence}

Bince Mani

区 binsnm@gmail.com

\begin{abstract}
Endopogon versicolor Wight, previously treated as a synonym of Strobilanthes cuspidata (Benth.) T. Anderson, is reinstated as a distinct species and a new name $S$. benthamii B. Mani, Sinj. Thomas, Britto, A.K. Pradeep, Y.F. Deng \& E.S.S. Kumar is necessarily proposed here. It differs from $S$. cuspidata by the stem and leaf indumentum, bract/calyx length ratio, corolla shape, pollen morphology, etc. Detailed descriptions, illustrations, pollen morphology and comparison with similar species are provided.
\end{abstract}

Keywords: Acanthaceae; Endopogon; Strobilanthes; Nomenclature; Pollen; Taxonomy

Citation: Thomas S, Mani B, Britto SJ, Deng Y, Pradeep AK, Kumar ESS. Notes on Strobilanthes cuspidata complex (Acanthaceae). Plant Science Today 2020;7(1):29-38. https://doi.org/10.14719/pst.2020.7.1.627

Copyright: (C) Thomas et. al. (2020). This is an open-access article distributed under the terms of the Creative Commons Attribution License, which permits unrestricted use, distribution, and reproduction in any medium, provided the original author and source are credited (https://creativecommons.org/licenses/by/4.0/).

Indexing: Plant Science Today is covered by Scopus, Web of Science, BIOSIS Previews, ESCI, CAS, AGRIS, UGC-CARE, CABI, Google Scholar, etc. Full list at http://www.plantsciencetoday.online 
and four-seeded capsules. Endopogon hypoleucus Nees var. $\beta$ differs from var. $\alpha$ by its campanulate corolla and it was later described as a new species by Carine et al. (8) as Strobilanthes carnatica Carine, J.M.Alexander \& Scotland. Several years later Nees described six additional taxa of Endopogon including E. viscosus Arn. ex Nees from Ceylon (Sri Lanka) with a variety viz. var. humilis Wight from Courtallum, Tamil Nadu based on Wight's collections.

In his Icones Plantarum Indiae Orientalis, Wight (9) described Endopogon to possess those species having campanulate-infundibuliform corolla, two stamens and capsules with four seeds. Later, the diagnostic features of bilabiate vs. campanulate corolla caused taxonomic confusion. Simultaneously, Wight (9) described and illustrated (t. 1497) a new species, E. versicolor from the Nilgiris, which has campanulate corolla. In the protologue, Wight compared Endopogon versicolor with $E$. hypoleucus which has bilabiate and ventricose corolla. Therefore, it is now presumed that both Nees and Wight did not give due weightage on the shape of the corolla while preparing the description of these species. Furthermore, the material (Wight n. 1497, Neilgherries) used by him has campanulate corolla. It could be presumed that Wight may erroneously labelled the material when he described and illustrated the species E. versicolor using Wight 1498 and hence annotated "Endopogon versicolor, Icones 1498, Neilgherries" on that specimen. Later, Clarke (10) corrected it as "Wight Ic. t. 1497". It is now evident that the Icones 1498 is E. viscosus Nees var. humilis and was labelled as "Endopogon viscosus var. humilis, Ic. 1498, Courtallum". The latter is totally different from the former and the illustration and description of Icones No. 1498 matches with the latter only. Wight (11) again published the same illustration of $E$. versicolor in Illustrations of Indian Botany.

Anderson (12-13) merged Endopogon with Strobilanthes and treated it as a subgenus, Strobilanthes subgen. Endopogon (Nees) Anderson, and listed E. versicolor under synonymy of both Strobilanthes cuspidatus (Bentham) Anderson and $S$. viscosus (Arnott ex Nees) T. Anderson. He considered that Wight's description in the text of $t$. 1497 is referred only to S. cuspidatus while the illustration of t. 1497 is identical with $S$. viscosus (13). Accordingly, E. versicolor was subsequently reduced to $S$. cuspidatus by Clarke (10) or $S$. viscosus by Beddome (14). Clarke's treatment was followed by several authors (15-18).

Strobilanthes cuspidatus was originally described as E. cuspidatus Bentham (19) based on Hohenacker's meterial (Hohenacker 1169, K) collected from Neilgherries (Nilgiris). It is similar to E. hypoleucus in having spicate inflorescence, bilabiate corolla and four seeded capsules. Since then, it has been collected from different regions of the Neilgherries evidently by the specimens housed at K, E, OXF, BM, CAL, MH, and TBGT. After perusal of specimens and digital images, it is confirmed that there are two different morphotypes of plants involved in these collections. One with campanulate corolla and the others with bilabiate corolla. It is interesting to note that the E. cuspidatus is quite distinct by its bilabiate and ventricose corolla, whereas $E$. versicolor is having subequal corolla lobes.

In his Icones Plantarum Indiae Orientalis, Beddome (14) provided the description and illustration for $S$. cuspidatus and synonymized $E$. versicolor under $S$. viscosus. However, the illustration he provided for the species has a perfect match with E. versicolor.

When Carine et al. (8) presented a detailed account on S. kunthiana (Nees) T. Anderson ex Benth. group (Phlebophyllum sensu Bremekamp), they adopted the treatment of Clarke to treat $E$. versicolor as the synonym of S. cuspidata. They also stated that corolla of $S$. cuspidata is campanulate to subventricose and illustrated as such. It is apparent that they examined materials of both E. versicolor and E. cuspidatus for the description provided. They also pointed out that Anderson (12) erroneously treated illustration of E. versicolor (Wight t. 1497) as E. viscosus and they considered $S$. cuspidata to be endemic to the Nilgiris.

In the present paper, we revised the taxonomic problems on $S$. cuspidata and $E$. versicolor on the basis of the analysis of gross vegetative morphology and palynological characters using fresh specimens, herbarium materials and literature. Pollen grains were collected from fresh specimens of all the taxa. The grains were washed in water by sonication. The air dried pollens were fixed to aluminium stubs and sputter-coated with gold. Morphological observations were made and micrographs were then taken with JEOL (JSM-6390LV/JED-2300) SEMEDS. The variability of pollen morphology in Strobilanthes is potentially a useful character to delimit taxa in this group (3, 6, 20-21). Endopogon versicolor differs from $S$. cuspidata by its campanulate corolla and apiculate pollen grains with straight ribs. Therefore, E. versicolor is absolutely different from $S$. cuspidata and allied to $S$. carnatica whereas E. cuspidatus is allied to $S$. consanguinea as Bentham stated.

Accordingly, E. versicolor is reinstated here as an independent species in Strobilanthes. Since the name $S$. versicolor Diels (22) antedated for a Chinese species, a new name $S$. benthamii is proposed here to accommodate $E$. versicolor.

\section{Taxonomy}

Strobilanthes benthamii B. Mani, Sinj. Thomas, Britto, A.K. Pradeep, Y.F. Deng \& E.S.S. Kumar, nom. nov. (Fig. $1 \&$ 2) 

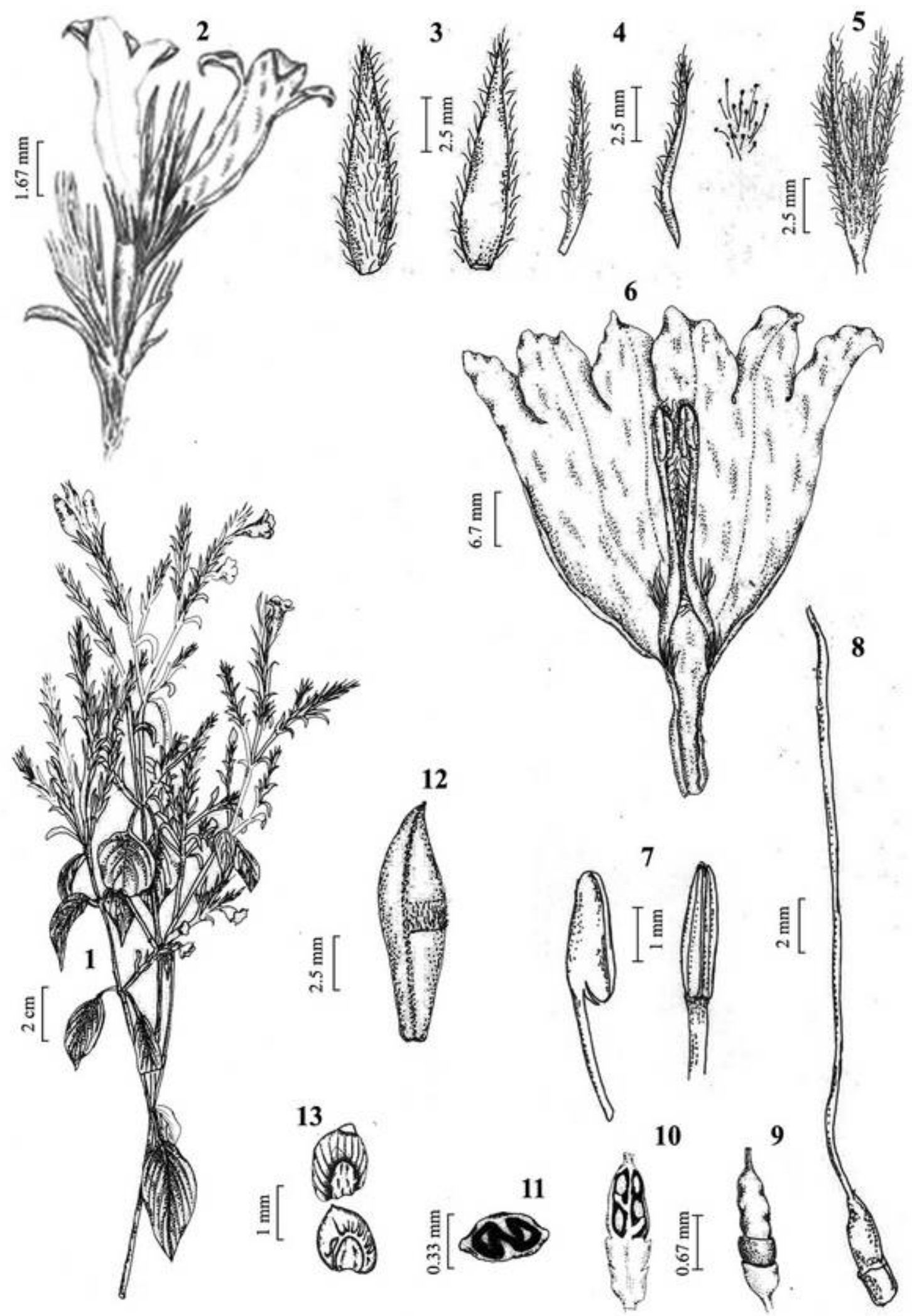

Fig. 1. Strobilanthes benthamii. 1. Habit; 2. Inflorescence; 3. Bract; 4. Bracteole; 5. Calyx; 6. Corolla split opened; 7. Anther; 8. Pistil; 9. Ovary; 10. Ovary L.S.; 11. Ovary T.S.; 12. Fruit; 13. Seeds (RHT68803). Illustrated by Philominal Selvi.

Replaced name: Endopogon versicolor Wight, Icon. P1. Ind. Orient. 4(3): 19, t. 1497 (1849).

- Phlebophyllum versicolor (Wight) Bremek. in Verh. Kon. Ned. Akad. Wetensch., Afd. Natuurk., Sect. 2, 41(1): 169 (1944), non Strobilanthes versicolor Diels (1912: 163).
Type: INDIA. Tamil Nadu: Neilgherries, Wight s.n. [1498] (lectotype designated here, K000882933, image!). Syntypes: INDIA. Peninsula Indiae, Wight 2206 (K000882934: image!); Tamil Nadu: Neilgherries, Wight s.n. (K000882935: image!); Wight s.n. (K000882936: image!). 

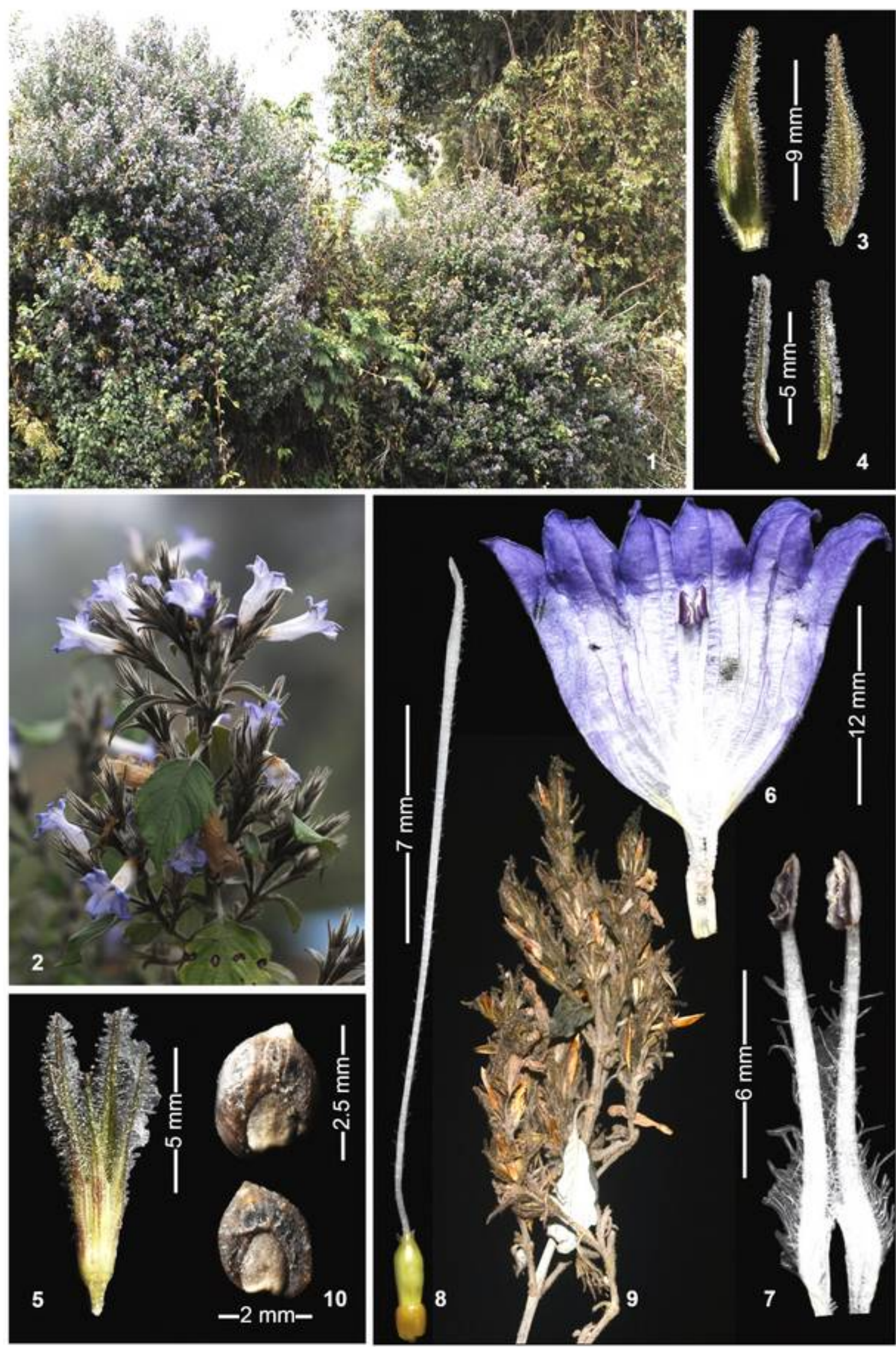

Fig. 2. Field images of Strobilanthes benthamii. 1. Habit; 2. Inflorescence; 3. Bract; 4. Bracteole; 5. Calyx; 6. Corolla split opened; 7. Stamen; 8. Pistil; 9. Infructescence; 10. Seeds.

Shrubs, up to $2.5 \mathrm{~m}$ high. Stem quadrangular (young) to terete (mature), young stem covered with dense sericeous indumentum, glandular hairy on uppermost sections at anthesis. Leaves opposite, slightly asymmetrical; petioles to $7.0 \mathrm{~cm}$ long, tomentellous; lamina ovate-elliptic, 
$3.0-13.2 \times 1.8-8.6 \mathrm{~cm}$, shortly decurrent at base, slightly crenate along margins, acuminate-acute at apex, abaxilly dense white sericeous, adaxially glabrous; lateral veins 7-12 pairs, prominent abaxially, less so adaxially. Inflorescence of an uninterrupted to interrupted spikes, $1.7-11.5 \mathrm{~cm}$ long, 4-7 mm broad, glandular hairy (viscous); axis glandular pubescent; flowers in opposite pairs. Bracts lanceolate, 11.0-12.5 × 2-3 mm, longer than calyx at anthesis, acuminate at apex, often recurved, glandular hairy along margins, abaxially glandular hairy, adaxially glandular-hairy at apex. Bracteoles linear, 8-9 mm long, abaxially glandular hairy, adaxially pubescent; secondary flower buds present. Calyx 5-lobed; two lobes shorter than other three, fused from base for $1 / 3-1 / 2$ of length at anthesis; lobes lanceolate, 9-11 mm long, acute at apex, abaxially glandular-hairy, adaxially pubescent. Corolla bluish, $2.6-2.9 \mathrm{~cm}$ long; basal tube cylindrical; tube 6-7 mm long, glabrous; throat campanulate, $14-16 \mathrm{~mm}$ long, densely fine pubescent outside, inside long hairy along adaxial side; lobes equal, widely elliptic, 5$7.5 \times$ ca. $6 \mathrm{~mm}$, overlapping, fine pubescent outside, glabrous inside. Stamens 2, included, basally attached with corolla; anthers $1.8-2.5 \mathrm{~mm}$ long, thecae 2, violet, held parallel with filament; filaments $8-10 \mathrm{~mm}$ long, long white hairs for proximal $3 / 4$ length; Ovary $1.5-2 \mathrm{~mm}$ long, sparsely pubescent at apex, 2-locular; 2 ovules per locule; style 18-19 mm long, filiform, fine pubescent throughout; stigma 2.5-3.0 mm long, sparsely pubescent. Infructescence $7.5-11.4 \times 0.8-1.0 \mathrm{~cm}$, glandular hairy (viscous); calyx covering the capsule. Capsule oblanceolate, 11.0-12.0 × 3.0-3.5 $\mathrm{mm}$, apically pubescent. Seeds 4 (rarely 2 ), $2-3 \times 2-$ $2.5 \mathrm{~mm}$, ovate-wide elliptic, truncate at base, cuspidate at apex, densely pubescent.
Habitat and distribution: Strobilanthes benthamii grows as patches under moist deciduous forest and also on exposed slopes on hillsides at elevations ranging from 1100-1400 m a.s.l. in the eastern slopes of the Western Ghats.

Notes: Strobilanthes benthamii, a Nilgiri endemic, was wrongly treated by various authors $(8,13-14$, 16-20) since 1864. It was suggested to be similar to $S$. cuspidata in the characters of white sericeous indumentum on abaxial surface of the leaves, often uninterrupted glandular-viscous spikes, recurved bracts, unequal calyx lobes, included stamens, viscous infructescence and four seeded capsules. However, Strobilanthes benthamii can be easily distinguished from the latter in having white sericeous indumentum on young stem, glabrous adaxial leaf surface, bracts exceeding the calyx, campanulate corolla with equal lobes, elliptic anthers and prolate-apiculate pollen grain with straight ribs (Fig. 5.1 \& Table 1). Strobilanthes benthamii occurs in different parts of the Nilgiris even though each population has limited number of individuals.

Carine et al. 2004: 20 (8) indicated the type to be "Neilgherries, Wight s.n. (lectotype: K!)." However, this was not an effective lectotypification because they failed to use the phrase "designated here" (hic designatus) or an equivalent that required by Art. 7.11 of the ICN (23). Here, we formally designated the same specimen as the lectotype using the phrase "designated here".

Strobilanthes benthamii is also allied to $S$. carnatica Carine et al. (8), but differs by robust habit, glandular hairy stem at anthesis, ovateelliptic leaves with acuminate-acute apex, 7-12 pairs of lateral veins, white sericeous abaxial

Table 1. Comparison of pollen features of S. benthamii, S. carnatica, S. cuspidata and S. consanguinea.

\begin{tabular}{llllllll}
\hline Species & Pollen class & Shape & Pseudocolpi & P $(\boldsymbol{\mu m})$ & E $(\boldsymbol{\mu m})$ & P:E ratio & Ribs \\
\hline S. benthamii & Prolate & Apiculate & Moderately wide & $70-81$ & $51-55$ & 1.40 & 32-36, straight \\
\hline S. carnatica & Subprolate & Widely ovate & Narrow & $37-39$ & $29-31$ & 1.26 & 27 , straight \\
\hline S. cuspidata & Prolate & Terete & Wide & $47-52$ & $31-34$ & 1.50 & $16-18$, spiral \\
\hline S. consanguinea & Perprolate & Barrel & Narrow & $48-53$ & $24-26$ & 2.02 & $18-21$, spiral \\
\hline
\end{tabular}

Pollen morphology: Pollen grains are ellipsoid, tricolporate and contain pseudocolpi (Fig. 5.1). The grains are prolate in outline and fusiform. The exine divided into longitudinal ribs which are close, straight and tectate. Tectum perforates. A comparison of pollen features with allied species (Fig. 5.2) is given in Table 1.

Etymology: The species is named after George Bentham for his contributions to the field of Botany.

Phenology: Flowering January-March; seed dispersal starts in April. indumentum on leaves, often uninterrupted broad spikes which are viscous, bracts exceeding the calyx, larger corolla, widely elliptic corolla lobes, prolate-apiculate pollen grains with moderately wide pseudocolpi (Fig. 5.1 \& Table 1 \& 2), pubescent style and stigma and oblanceolate and puberulent capsules. Moreover, S. carnatica is distributed in the Eastern Ghats only (8).

Specimens examined: INDIA. Tamil Nadu: Nilgiri district, Sigur, $1800 \mathrm{~m}$ a.s.l., Nov 1884, Gamble 15670 (MH); Nilgiris, $1500 \mathrm{~m}$ a.s.l., 18 Feb 1972, Sharma 39843 (MH); Nilgiris, $1800 \mathrm{~m}$ a.s.l., 29 Jan. 1972, Vajravelu 39696 (MH); Nilgiris, $1650 \mathrm{~m}$ a.s.l., 5 Jan 2017, Pradeep et al. 68493 (RHT); 1 Apr 2017, 
Pradeep et al. 68596 (RHT); 16 Jan 2018, Pradeep et al. 68803 (RHT); 12 Feb 2018, Pradeep et al. 68804 (RHT); 11 Mar. 2018, Pradeep et al. 68805 (RHT).

Strobilanthes cuspidata (Benth.) T. Anderson, J. Linn. Soc., Bot. 9: 465 (1867). (Fig. 3 \& 4)

Basionym: Endopogon cuspidatus Benth., Linnaea 24: 646 (1851). long, fine pubescence outside, inner side with two lines of long white hairs on the adaxial side; lobes unequal, folded back, two adaxial lobes partly fused and hooded, widely elliptic, 1.1-1.3 × 1.0-1.2 $\mathrm{cm}$, fine pubescent outside, glabrous inside. Stamens 2, included; filaments 1.1-1.15 cm long, glabrous except at point of fusion with corolla; anthers sagittate, 3.5-4.0 $\times$ ca. $1 \mathrm{~mm}$, thecae 2, held parallel to filament. Ovary $2.5-3 \mathrm{~mm}$ long, apex

Table 2. Comparison of morphological characters of S. benthamii and S. cuspidata

\begin{tabular}{lll}
\hline Characters & S. benthamii & S. cuspidata \\
\hline Stem (young) & & \\
\hline \multicolumn{1}{c}{ Indumentum } & Sericeous & Tawny tomentose \\
\hline Leaf blade & & \\
\hline Shape & Ovate to elliptic & Ovate \\
Apex & Acuminate to acute & Acuminate to cuspidate \\
Margin & Slightly crenate & Entire or slightly crenate \\
Adaxial indumentum & Glabrous & Pubescent \\
\hline Bract & & \\
\hline Adaxial indumentum & Glandular hairy at apex & Glandular hairy at upper $1 / 2$ part \\
Bract:calyx ratio & Longer & Shorter \\
\hline Corolla & & \\
\hline Shape & Campanulate & Ventricose \\
\hline Stamens & & Glabrous \\
\hline Filaments & Long white hairs for proximal $3 / 4$ length & Sagittate \\
Anthers & Elliptic & \\
\hline
\end{tabular}

Type: INDIA. Tamil Nadu: Nilgiris, Hohenacker 1169 (lectotype designated by Carine et al., K000882938; E00160838, MPU018233, images!, U0000079 image!), LECB0001800 image!, JE 00002184 image!, JE 00002185 image!, JE 00002186 image!, HAL 0113941 image!).

Shrubs, up to $1.5 \mathrm{~m}$ high. Stem quadrangular to terete; young stem tawny tomentose; mature stem lenticellate. Leaves opposite, symmetric; petioles $3.5-7.0 \mathrm{~cm}$ long, tomentose; blade ovate, $4.8-12.5 \times 2.5-7.6 \mathrm{~cm}$, shortly decurrent onto the petiole at base, entire or slightly crenate along margins, acuminatecuspidate at apex, densely tawny hairy on both surfaces when young, becoming white sericeous abaxially and pubescent adaxially; lateral veins 612 pairs, prominent on both surfaces, raised beneath. Inflorescence of often uninterrupetd spikes, 3.2-9.0 $\times 0.7-0.8 \mathrm{~mm}$ at anthesis, glandular hairy (viscous); peduncle covered with glandular hairs; flowers in opposite pairs. Bracts lanceolate, 10-11 × 2.5-3.0 mm, shorter than calyx at anthesis except for lowermost ones, acuminate at apex, recurved, abaxially glandular hairy, adaxially glandular hairy on upper $1 / 2$ portion. Bracteoles linear, 9-10 mm long, abaxially glandular hairy, adaxially pubescent; secondary flower buds present. Calyx 5-lobed; two lobes shorter than other three, fused from base for $1 / 3-2 / 3$ of length at anthesis; lobes lanceolate, 1.1-1.2 cm long, acuminate at apex, abaxially densely glandular hairy, adaxially fine pubescent. Corolla bluish, 2.7$2.9 \mathrm{~cm}$ long, inflated, basal tube cylindrical, 6.5-8.0 $\mathrm{mm}$ long, glabrous; throat ventricose, $1.4-1.5 \mathrm{~cm}$ glandular pubescent; style ca. $1.7 \mathrm{~cm}$ long, filiform, fine hairs present on lower $3 / 4$ portion; stigma linear, ca. $2.5 \mathrm{~mm}$ long, fine pubescent. Infructescence $4.0-14.0 \times 0.8-1.0 \mathrm{~cm}$, densely glandular hairy (viscous). Capsule oblanceolate, $0.9-1.2 \times 0.3-0.4 \mathrm{~cm}$, hairy at apex. Seeds 4, 1.5-2.5 $\times 1.5-2 \mathrm{~mm}$, widely elliptic-orbicular, truncatedsemi-rounded at base, rounded at apex, densely pubescent.

Pollen morphology: Pollen grains are ellipsoid, tricolporate and have pseudocolpi (Fig. 5.3). The outline of the pollen is prolate (cylindrical) and exine is divided into longitudinal ribs which are thick, punctate, distant, spiral and tectate. Tectum perforates. Pollen features of allied species (Fig. 5.4) are given in Table 1.

Phenology: Flowering January-March and it follows a semelparous life history pattern; fruiting April-May.

Habitat and Distribution: It grows as shola forest undergrowth at elevations ranging from 17502000 m a.s.l. in Nilgiris, Tamil Nadu.

Notes: Strobilanthes cuspidata, a species endemic to Nilgiris with narrow distribution, has often been confused with $E$. versicolor by many authors. Bentham (19) described the species based on Hohenacker's collection without providing an illustration. Anderson, Beddome and Clarke wrongly synonymised $E$. versicolor under $S$. cuspidata and followed by others $(8,15-17)$. This species is definitely distinguished from $E$. versicolor (S. benthamii) by the characters of tawny tomentum on young stems, leaves with adaxial 

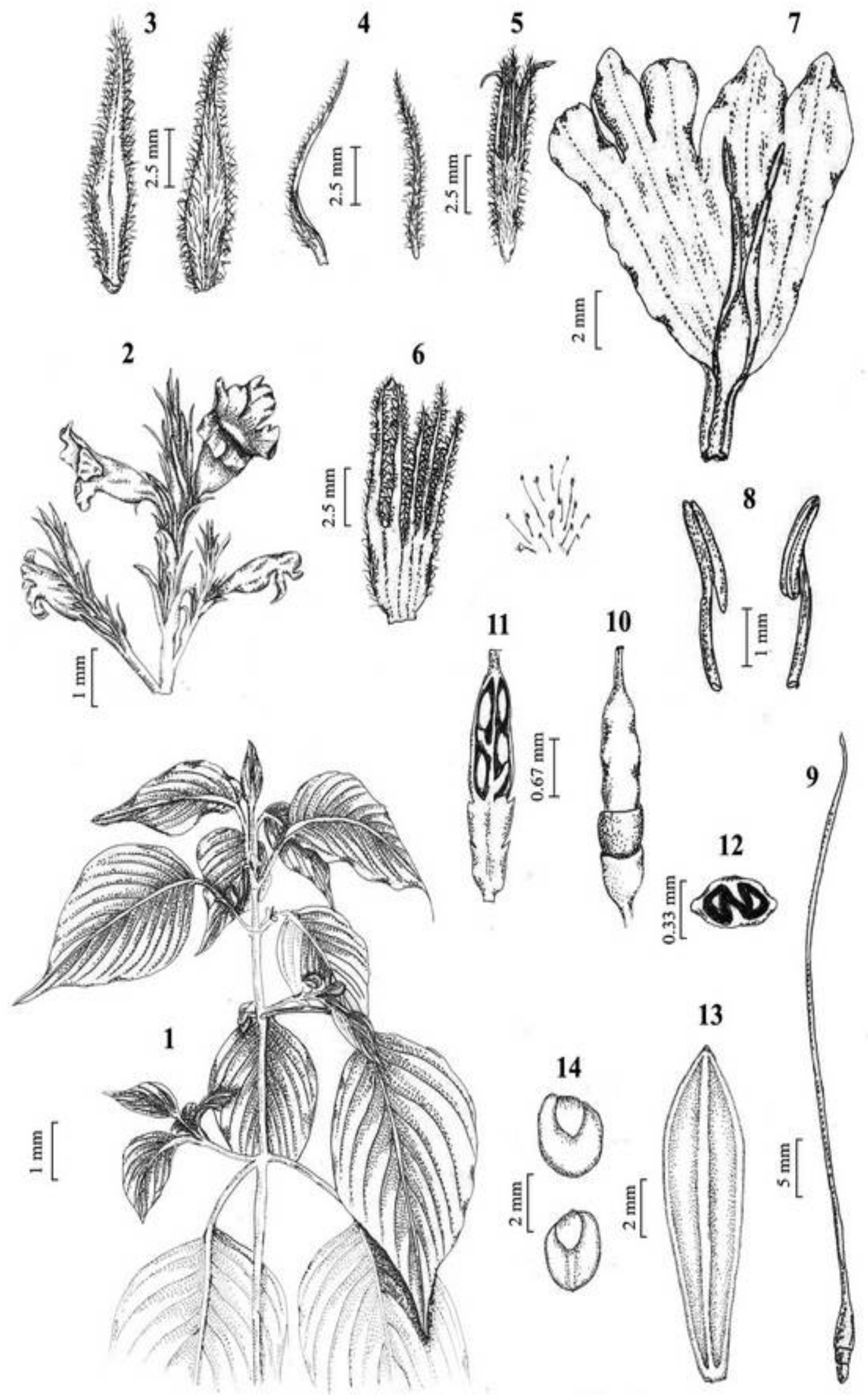

Fig. 3. Strobilanthes cuspidata. 1. Habit; 2. Inflorescence; 3. Bract; 4. Bracteole; 5. Calyx; 6. Calyx split opened; 7. Corolla split opened; 8. Anther; 9. Pistil; 10. Ovary; 11. Ovary L.S.; 12. Ovary T.S.;13. Fruit; 14. Seed (RHT68806). Illustrated by Philominal Selvi. 

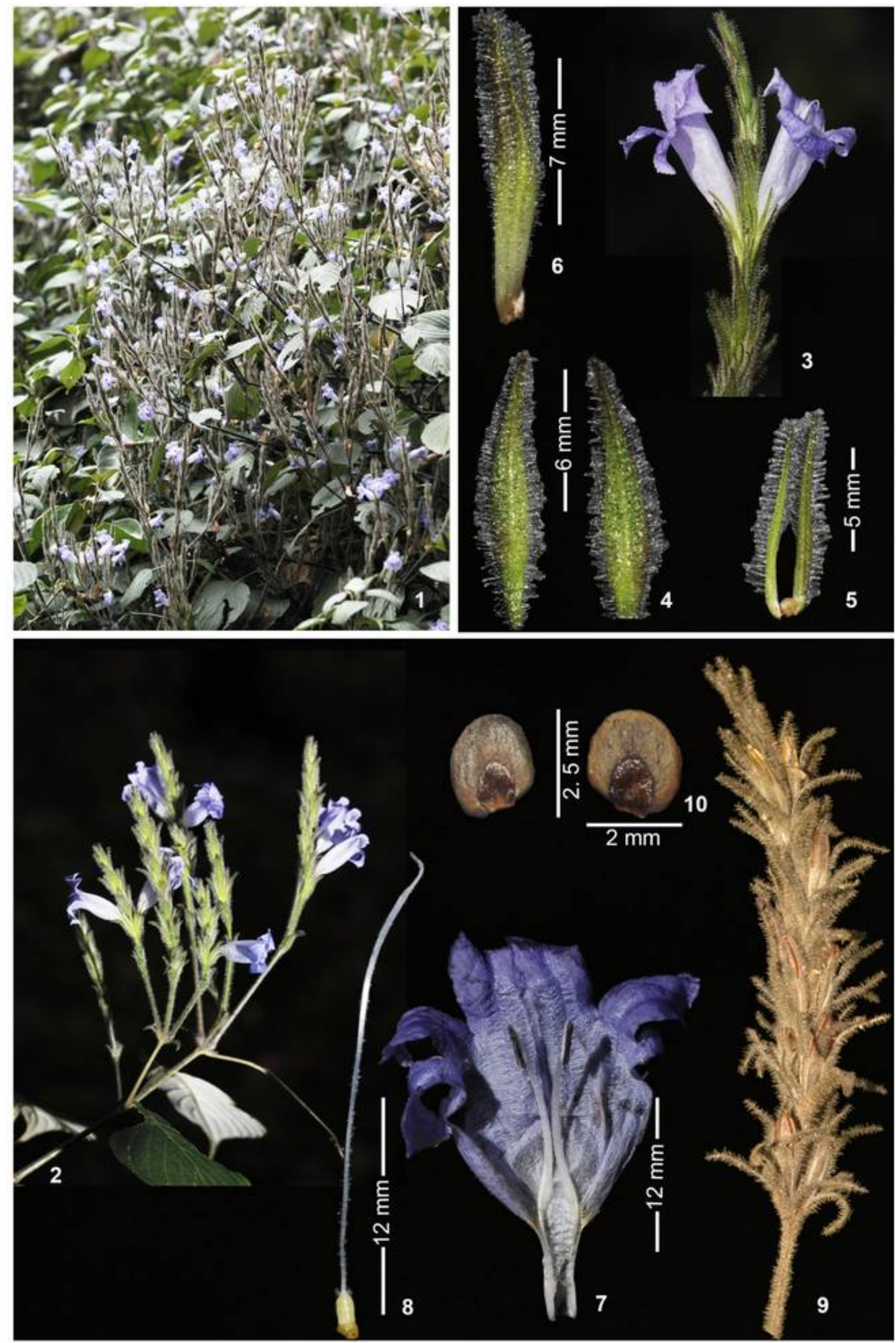

Fig. 4. Field images of Strobilanthes cuspidata. 1. Habit; 2. Inflorescence; 3. Pair of flowers; 4. Bract; 5. Bracteole; 6. Calyx; 7. Corolla split opened; 8. Pistil; 9. Infructescence; 10. Seeds. 

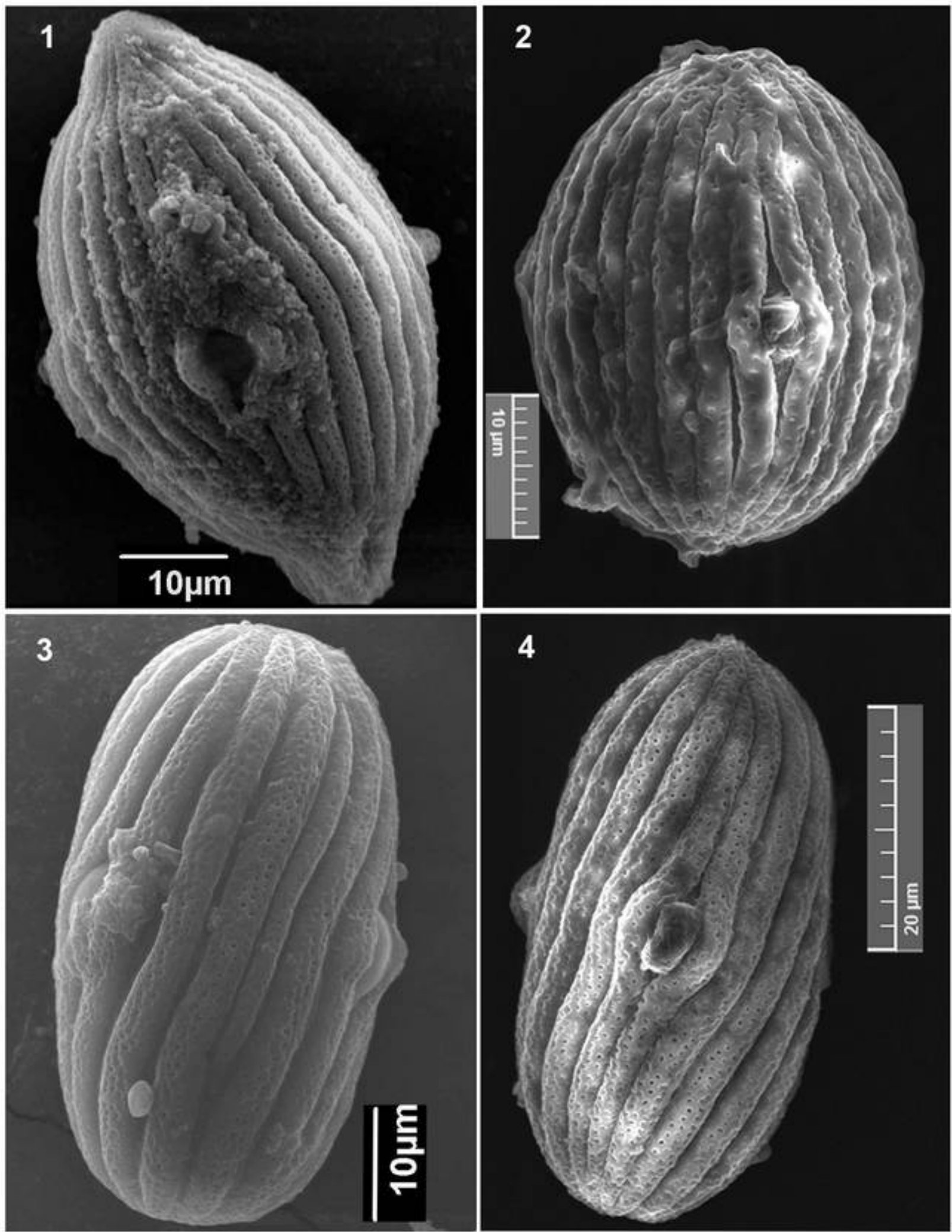

Fig. 5. Scanning electron micrographs (SEM) of pollen grains of $S$. benthamii (1), S. carnatica (2), S. cuspidata (3) and S. consanguinea.

pubescence, bracts being shorter than calyx, ventricose corolla with unequal lobes in which adaxial lobes are hooded, with sagittate anthers, prolate-barrel shaped pollen grains with spiral ribs (Fig. 5.3 \& Table $1 \& 2$ ).
It is allied to $S$. consanguinea (Nees) $\mathrm{T}$. Anderson, which is widely distributed in the Western Ghats. However, it can be easily distinguished from the latter by having tawny young stem (vs. glabrous or rarely pubescent young stem), strictly white sericeous abaxial leaf indumentum (vs. glabrous or rarely white 
indumentum on abaxial leaf surface), broad spikes (vs. narrow spikes) strictly glandular hairy (viscous) floral parts such as peduncle, bracts, bracteoles and calyx (vs. glabrous or rarely sparsely pubescent or glandular floral parts at the time of anthesis), bracts shorter than calyx (vs. bracts equal to the calyx), presence of secondary flower buds in the axis of bracteole (vs. absence of secondary flower buds), unequal calyx lobes (vs. equal), long corolla (vs. short corolla), widely elliptic corolla lobes (vs. narrowly traingular), included stamens (vs. exserted), sagittate anther (vs. elliptic) and pubescent style (vs. glabrous style).

The pollen morphology of $S$. cuspidata (Fig. 5.3) differs from that of $S$. consanguinea (Fig. 5.4) in having cylindrical pollen grains with only 16-18 ribs which are wide and prominent and wide pseudocolpi. Therefore, S. cuspidata is totally different from $S$. consanguinea. Moreover, it also ascertains that this enigmatic taxon has a very narrow distribution and it might be rarely found the specimens in herbaria.

Specimens examined: INDIA. Tamil Nadu: Nilgiri District, Nilgiri, 10 Dec 1957, Sebastine 4886 (MH); 15 Jan. 2018, Pradeep et al. 68806 (RHT); 30 Jan. 2018, Pradeep et al. 68818 (RHT); 12 Feb. 2018, Pradeep et al. 68807 (RHT); 11 Mar 2018, Pradeep et al. 68808 (RHT).

\section{Competing interest}

Authors declare that they have no competing interest.

\section{Authors' contributions}

All authors contributed equally to the present work.

\section{Acknowledgements}

We would like to express our gratitude to the curators of BM, C, CAL, CALI, E, K, MH, P, and TBGT for the kind permission for herbarium analysis and providing digital images of the specimens. The authors are indebted to staff of the Rapinat Herbarium for technical support.

\section{References}

1. Blume CL. Bijdragen tot de Flora van Nederlandsch Indie 14. Batavia: Ter Lands Drukkerij; 1826 http://dx.doi.org/10.5962/bhl.title.395

2. Mabberley DL. Mabberley's Plant-book. 4th ed. Cambridge: Cambridge University Press; 2017.

3. Nees von Esenbeck CGD. Acanthaceae Indiae Orientalis. In: Wallich $\mathrm{N}$, editor. Plantae Asiaticae rariores. vol. 3. London, Paris \& Strasburg: Treuttel \& Wurtz; 1832. p. 7576, 83, 98-99. https://biodiversitylibrary.org/item/9716

4. Bremekamp CEB. Materials for a monograph of the Strobilanthinae (Acanthaceae). Verh. Kon. Ned. Akad. Wetensch., Afd. Natuurk., Tweede Sect. 1944; 41:1-305.
5. Moylan EC, Bennett JR, Carine MA, Olmstead RG, Scotland RW. Phylogenetic relationships among Strobilanthes s.1. (Acanthaceae): evidence from ITS nrDNA, trnL-F cpDNA, and morphology. Am J Bot. 2004;91:724-35. https://doi:10.3732/ajb.91.5.724

6. Tripp EA, Daniel TF, Fatimah S, McDade LA. Phylogenetic Relationships within Ruellieae (Acanthaceae) and a Revised Classification. Int J Plant Sci. 2013;174:97-137. http://www.jstor.org/stable/10.1086/668248

7. Deng YF, Wood JRI, Scotland RW. New and reassessed species of Strobilanthes (Acanthaceae) in the Flora of China. Bot J Linn Soc. 2006;150:369-90. https://doi.org/10.1111/j.1095-8339.2006.00473.x

8. Carine MA, Alexander JM, Scotland RW. A revision of the Strobilanthes kunthiana-group (Phlebophyllum sensu Bremekamp) (Acanthaceae). Kew Bull. 2004;59:1-25.

9. Wight R. Icones Plantarum Indiae Orientalis. vol. 4 Madras: J.B. Pharoah; 1849. p. 19, t.1497. https://www.biodiversitylibrary.org/item/1859

10. Clarke CB. Acanthaceae. In: Hooker JD, editor. Flora of British India. vol. 4. London: L. Reeve; 1884. http://www.biodiversitylibrary.org/bibliography/678

11. Wight R. Illustrations of Indian Botany. vol. 2. Madras: American Mission Press; 1850. p.191, t.164b. https://www.biodiversitylibrary.org/item/39780

12. Anderson T. Acanthaceae. In: Thwaites GHK, editor Enumeratio Plantarum Zeylaniae. London: Dulau; 1864. p. 223-26.

13. Anderson T. An enumeration of the Indian species of Acanthaceae. J Linn Soc, Bot. 1867. 9:425-526. https://www.biodiversitylibrary.org/item/8360

14. Beddome RH. Icones Plantarum Indiae Orientalis. vol. 1. Madras: Gantz Brothers; 1874. p. 53-54, t.221.

15. Fyson PF. The Flora of the Nilgiri and Pulney Hill-tops. vol. 1. Madras: The Superintendent, Govt. Press; 1915. p. 312-13, t. 207. https://doi.org/10.5962/bhl.title.10798

16. Gamble JS. Flora of the Presidency of Madras. vol. 2. London: West, Newman \& Adlard; 1924. p. 1025-44. https://www.biodiversitylibrary.org/item/10372

17. Venu P. Strobilanthes Blume (Acanthaceae) in Peninsular India. Kolkata: Botanical Survey of India; 2006.

18. Noltie HJ. The botany of Robert Wight. Verlag: A.R.G. Gantner; 2005.

19. Bentham G. Acanthaceae Novae Inter Plantas Nilgherrenses Hohenackeri. Linnaea 1851;24:646-47. https://www.biodiversitylibrary.org/item/10868

20. Terao H. Observations on the echinulate pollen of Strobilanthes s.l. and its allies. Acta Phytotax Geobot 1982;33:371-79.

21. Carine MA, Scotland RW. Pollen morphology of Strobilanthes Blume (Acanthaceae) from southern India and Sri Lanka. Rev Palaeobot Palynol. 1998;103:143-65. https://doi.org/10.1016/S0034-6667(98)00030-X

22. Diels L. Plantae Chinese Forrestianae: New and imperfectly known species. Notes Roy Bot Gard Edinburgh 1921;5:163 https://www.biodiversitylibrary.org/item/96820

23. Turland NJ, Wiersema JH, Barrie FR, et al., editors. International Code of Nomenclature for algae, fungi, and plants (Shenzhen Code) adopted by the Nineteenth International Botanical Congress Shenzhen, China, July 2017. Regnum Vegetabile 159. Glashütten: Koeltz Botanical Books; 2018. https://doi.org/10.12705/Code.2018 